\title{
A NEW ODONTORHYTIS SPECIES (CHONDRICHTHYES) FROM THE MIDDLE EOCENE OF ELGEDIDA MINE, BAHARIYA OASIS, EGYPT
}

\author{
Iman Salame and Anhar Asan \\ Department of Geology, Faculty of Science, Ain Shams University, 11566 Cairo, Egypt
}

\begin{abstract}
During a systematic examination of a chondrichthyan assemblage collected from the middle Eocene (probably Lutetian) glauconitic sandstone bed overlying the iron ore of ElGedida mine, in the Bahariya oasis, the authors came across a large number of minute teeth belonging to genus Odontorhytis. By comparing these teeth to the already known species Odontorhytis pappenheimi from the middle-late Eocene (Bartonian-Priabonian) of Egypt, it appeared that they differ from the latter species by a number of consistent characters, and must be assigned to a new species-Odontorhytis bahariensis.
\end{abstract}

Keywords: Odontorhytis, new species, Chondrichthyes, Eocene, Egypt

\section{INTRODUCTION}

Genus Odontorhytis (type-species Odontorhytis pappenheimi Böhm, 1926) was initially created by Böhm (1926) as a member of the bony fishes (Class Actinopterygii, Family Lophiidae). We owe to Cappetta (1981) the first interpretation of this taxon as an authentic member of the elasmobranchs; its precise classification within this group remains, however, enigmatic to this day. According to Case \& Cappetta (1990), Odontorhytis pappenheimi has long been known from the middle or late Eocene (Bartonian or Priabonian) of Egypt (Priem, 1905) but had been erroneously assigned by this author to an indeterminate teleost fish of the Order Perciformes. It was rediscovered and redescribed in detail by Case \& Cappetta (1990) from the middle to late Eocene of the Fayum, in the Gehannam Formation and Qasr ElSagha Formation. In 2007, Strougo et al. reported, from the glauconitic sandstone overlying the iron ore at ElGedida mine (middle Eocene, probably Lutetian) of the Bahariya oasis, another species of Odontorhytis which seems to be more slender and less massive than O. pappenheimi. The species was left in open nomenclature by these authors awaiting further studies. Examination of newly collected material of this latter species from the same bed and locality from which it was first recorded leads us to conclude that it seems to represent a new species which we herein call Odontorhytis bahariensis.

\section{STRATIGRAPHICAL SETTING}

The Bahariya oasis is a closed oval-shaped depression stretching NE-SW, situated in the central region of the Western Desert of Egypt, nearly $320 \mathrm{~km}$ to the southwest of Cairo between (lat. $27^{0} 48^{\prime}-28^{0} 30^{\prime} \mathrm{N}$ and long. $28^{0} 35^{\prime}-29^{0} 10^{\prime} \mathrm{E}$ ) and has a surface area of $1,800 \mathrm{sq}$. $\mathrm{km}$. The rock succession exposed in the depression and on its walls ranges from Cenomanian to Oligocene (Said, 1990). On the plateau, close to the wall that bounds the Bahariya depression from the northeast, lies the ElGedida mine, a small depression hosting an ironstone deposit. An interval of glauconitic sandstone, a few meters thick, truncates the top of the iron ore and includes near its base a phosphatic band from which Strougo et al. (2007) were able to retrieve a somewhat diverse assemblage dominated by teeth of batoids, sharks, and bony fishes, along with small internal molds of bivalves, gastropods and serpulids. Most of the teeth have not been identified to the species level pending a more comprehensive study. The list of the fauna recovered by Strougo et al. (2007) from the glauconitic sandstone horizon is as follows: 


\section{Sharks:}

“Carcharias” koerti (Stromer, 1910)

Galeocerdo eaglesomei White, 1955

“Galeorhinus” sp.

Carcharhinus aff. frequens Dames, 1883

Rhizoprionodon sp.

Scyliorhinus sp.

Chiloscyllium sp.1

Chiloscyllium sp.2

Hemiscyllium $s p$.

Odontorhytis sp.

\section{Batoids:}

Ouledia sp.

Rhinobatos $s p$.

Rhynchobatus sp.

Pristis? sp.

Dasyatis sp.1

Dasyatis sp.2

Dasyatis sp.3

Coupatezia sp.

Coupatezia? sp.

Leidibatis jugosus

Pseudaetobatus sp.

Rhinoptera sp.

Garabatis sp.

Burnhamia sp.

Archaeomanta sp.

\section{Bivalve molluscs:}

Calorhadia? sp.

Calorhadia? nilotica Strougo, 1976

Mesosaccella? gizehensis (Cuvillier, 1935)

Cucullaea aff. sheikhfadli Strougo, 1985

«Striarca (Rectangularca)»sp.

Cossmannella aff. sheikhfadli Strougo, 1985

Caryocorbula sp.

Martesia sp. 


\section{Age of the fauna}

There is general belief that the iron ore deposit of ElGedida is equivalent to the lower Eocene limestones, commonly called the Naqb Formation, capping the walls of the Bahariya depression from the north (Said \& Issawi, 1965; Basta \& Amer, 1969; El-Sharkawi et al., 1989; El Aref \& Lotfi, 1989; Helba et al., 2001). As concerns the overlying glauconitic horizon, it has been generally correlated with the ElHamra Formation (Bartonian to Priabonian) of Said \& Issawi (1965), and assigned different ages, ranging from Lutetian to Priabonian, with little evidence though, as discussed by Strougo et al. (2007). According to these latter authors, some elements of the fossil assemblage identified by them from the glauconitic horizon show strong affinities to exclusively Lutetian fossils described from the Nile Valley and west central Sinai (e.g., Cucullaea sheikhfadli and Cossmannella sheikhfadli) or to typically Lutetian fossils recorded from other parts of the world (e.g., "Carcharias" koerti and Galeocerdo eaglesomei). They declared that future work may show that the glauconitic sandstone of the ElGedida mine is probably older than the ElHamra Formation.

\section{SYSTEMATIC PALEONTOLOGY}

The teeth described in this study belong to the collection of Amin Strougo deposited in the Geological Museum of the University of Ain Shams. They have been collected from a phosphatic band intercalated in the lower part of the glauconitic sandstone that overlies the iron ore deposit of El Gedida Mine, Bahariya oasis, that very horizon from which Strougo et al. (2007) collected and described their elasmobranch fauna.

Abbreviations. ASUGM: Ain Shams University Geological Museum; rh: root height; th: tooth height.

Neoselachii incertae ordinis

Genus Odontorhytis Böhm, 1926

Odontorhytis bahariensis Salame \& Asan n. sp.

(Plate 1, Fig. 1-18)

2007 Odontorhytis sp.: Strougo, Cappetta \& Elnahas, p. 88, pl. 1, fig. 4a-c.

2010 Odontorhytis pappenheimi: Murray et al., p. 667, fig. 1A, B.

2011 Odontorhytis pappenheimi: Underwood et al., p. 55 and 57, fig. 5/Z, AA.

Etymology. From the Bahariya oasis, in the Western Desert of Egypt.

Material. Strougo's collection (ASUGM 0816; 0817). More than one hundred teeth.

Type Locality. ElGedida iron mine, Baharyia oasis, Egypt.

Type Horizon. Glauconitic sandstone overlying the iron ore deposit. Middle Eocene (probably Lutetian). 
Salame and Asan

\begin{tabular}{|c|c|c|c|}
\hline Sample ID & $\mathrm{rh}$ & th & $\mathrm{rh} / \mathrm{th}$ \\
\hline ASUGM 0816/1 & 2.48 & 4.60 & 0.54 \\
\hline ASUGM 0816/2 & 2.67 & 4.85 & 0.55 \\
\hline ASUGM 0816/3 & 1.96 & 4.85 & 0.40 \\
\hline ASUGM 0816/4 & 1.91 & 5.13 & 0.37 \\
\hline ASUGM 0816/5 & 3.13 & 6.55 & 0.48 \\
\hline ASUGM 0816/6 & 1.96 & 4.18 & 0.47 \\
\hline ASUGM 0816/7 & 1.75 & 3.98 & 0.44 \\
\hline ASUGM 0816/8 & 2.45 & 4.70 & 0.52 \\
\hline ASUGM 0816/9 & 2.07 & 5.54 & 0.37 \\
\hline ASUGM 0817/1 & 3.24 & 6.54 & 0.49 \\
\hline ASUGM 0817/2 & 2.59 & 4.88 & 0.53 \\
\hline ASUGM 0817/3 & 2.72 & 5.96 & 0.46 \\
\hline ASUGM 0817/4 & 2.97 & 5.99 & 0.49 \\
\hline ASUGM 0817/5 & 2.16 & 4.36 & 0.49 \\
\hline ASUGM 0817/6 & 1.96 & 3.82 & 0.51 \\
\hline ASUGM 0817/7 & 1.28 & 2.99 & 0.43 \\
\hline ASUGM 0817/8 & 2.27 & 5.27 & 0.43 \\
\hline ASUGM 0817/9 & 2.84 & 5.08 & 0.56 \\
\hline ASUGM 0817/10 & 2.41 & 4.73 & 0.51 \\
\hline ASUGM 0817/11 & 2.21 & 4.55 & 0.48 \\
\hline ASUGM 0817/12 & 2.00 & 4.10 & 0.49 \\
\hline ASUGM 0817/13 & 1.69 & 3.15 & 0.54 \\
\hline
\end{tabular}

All measurements are in millimeter

Description. This species has a homodont dentition. The teeth are relatively small (slightly less than 7 $\mathrm{mm}$ in total height), lingually directed, symmetrical and somewhat compressed mesio-distally with high, slender, narrow, pointed cusp which is markedly convex transversely in lingual view and concave in labial view. In some teeth the apex is recurved labially. The lingual face is devoid of a cutting edge except on its apical part which has a distinct barb. The labial face bears a salient, blade-like, cutting edge which extends 
from the apex down to approximately two-third of the crown; beyond that point the basal part of the crown is bluntly rounded. The enamel of the lingual face is marked by faint, long vertical striations which may extend to the apex and are bounded on the mesial and distal sides by a more salient, sharp ridge reminiscent of a cutting edge; beyond these ridges, the labial face bears shorter and more crowded striations that are restricted to the basal part of the cusp. The root is high (root height/total tooth height $=$ $0.37-0.55)$, strongly oblique, lingually directed, narrow mesio-distally, significantly narrower in its basal portion, with subcordiform to subpyriform outline. The profile of its basal face is distinctly concave, symmetrically divided into two parts by a narrow but deep furrow extending all the way from the crownroot junction to the base of the tooth; this furrow is not visible from the labial side. The labial face of the root is very much reduced in comparison to the lingual face.

Remarks. The teeth described above are in every respect identical to the Bahariya specimens discussed and illustrated by Strougo et al. (2007). They differ from Odontorhytis pappenheimi in being less massive, and in that their crown is relatively higher and the cutting edge of the labial face does not extend to the basal edge of the cusp, as is the case in O. pappenheimi. It is likely then that the teeth figured by Underwood et al. (2011) from the Qasr ElSagha Formation of Wadi Hitan should be placed in our species. Adnet et al. (2010) recorded from the middle-late Eocene of Morocco teeth of an Odontorhytis species which they considered could be different from typical O. pappenheimi «in having a more slender cusp and less massive root». These are some of the characters we discussed above that distinguish our species from O. pappenheimi. Teeth of a probable O. pappenheimi have also been reported by Adnet et al. (2011) from the late Eocene Qasr ElSagha Formation of the northern plateau of the Bahariya oasis (O. aff. pappenheimi); these are, however, twice as large as the usual size of the species (15 $\mathrm{mm}$ in total height); their precise specific allocation must await further studies.

Geographic and stratigraphic distribution. Genus Odontorhytis is widely distributed in the Eocene of Africa, from Namibia, in the southern part of the continent, through Mali and Nigeria in the west central and western parts to Morocco and Egypt in the north (Böhm 1926; Cappetta 1981, 1987; Tabuce et al. 2005; Strougo et al. 2007; Murray et al. 2010; Adnet et al. 2011; Underwood et al. 2011. It would possibly occur also in the late Eocene of Pakistan (Case \& West 1991).

\section{ACKNOWLEDGMENTS}

The authors are deeply grateful to Prof. Amin Strougo, Ain Shams University, who kindly provided the fossil specimens for this study and for his valuable comments.

\section{REFERENCES}

Adnet, S., Cappetta, H. and Tabuce, R. (2010): A Middle-Late Eocene vertebrate fauna (marine fish and mammals) from southwestern Morocco; preliminary report: Age and palaeobiogeographical implications. Geological Magazine, 147/6: 860-870.

Adnet, S., Cappetta, H., Elnahas, S., and Strougo, A. (2011): A new Priabonian Chondrichthyans assemblage from the Western desert, Egypt: Correlation with the Fayum oasis. Journal of African Earth Sciences, 61/1: 27-37.

Basta, E. Z. and Amer, H. I. (1969): El-Gidida iron ores and their origin, Bahariya Oases, Western Desert, U.A.R. Economic Geology, 64: 424-444.

Böhm, J. (1926): Über tertiäre Versteinerungen von den Bogenfelser Diamantfeldern. Die Diamantenwüste Südwestafrikas. Beiträge zur Geologischen Erforschung der Deutschen Schutzgebiete, 2: 55-87.

Cappetta, H. (1981): Additions à la faune de sélaciens fossiles du Maroc: 1: Sur la présence des genres Heptranchias, Alopias et Odontorhytis dans 1'Yprésien des Ouled Abdoun. Géobios, 14/5: 563-575.

Cappetta, H. (1987): Handbook of paleoichthyology. V. 3B, Chondrichthyes II, Mesozoic and Cenozoic Elasmobranchii. Gustav Fischer Verlag, Stuttgart, 193 p. 
Salame and Asan

\section{EXPLANATION OF PLATE}

\section{Odontorhytis bahariensis Salame \& Asan n. sp.}

(1-3): Labial, lateral, and lingual views; (4-6): Labial, lateral, and lingual views of another specimen; (7-9): Labial, lateral, and lingual views of another specimen; (10-12): Labial, lateral, and lingual views of another specimen; (13-15): Labial, lateral, and lingual views of another specimen, Holotype; (16-18): Labial, lateral, and lingual views of another specimen. Strougo's collection, ASUGM 0817; glauconitic sandstone of the ElGedida mine; middle Eocene (probably Lutetian). 
New Odontorhytis species from the Eocene of Egypt

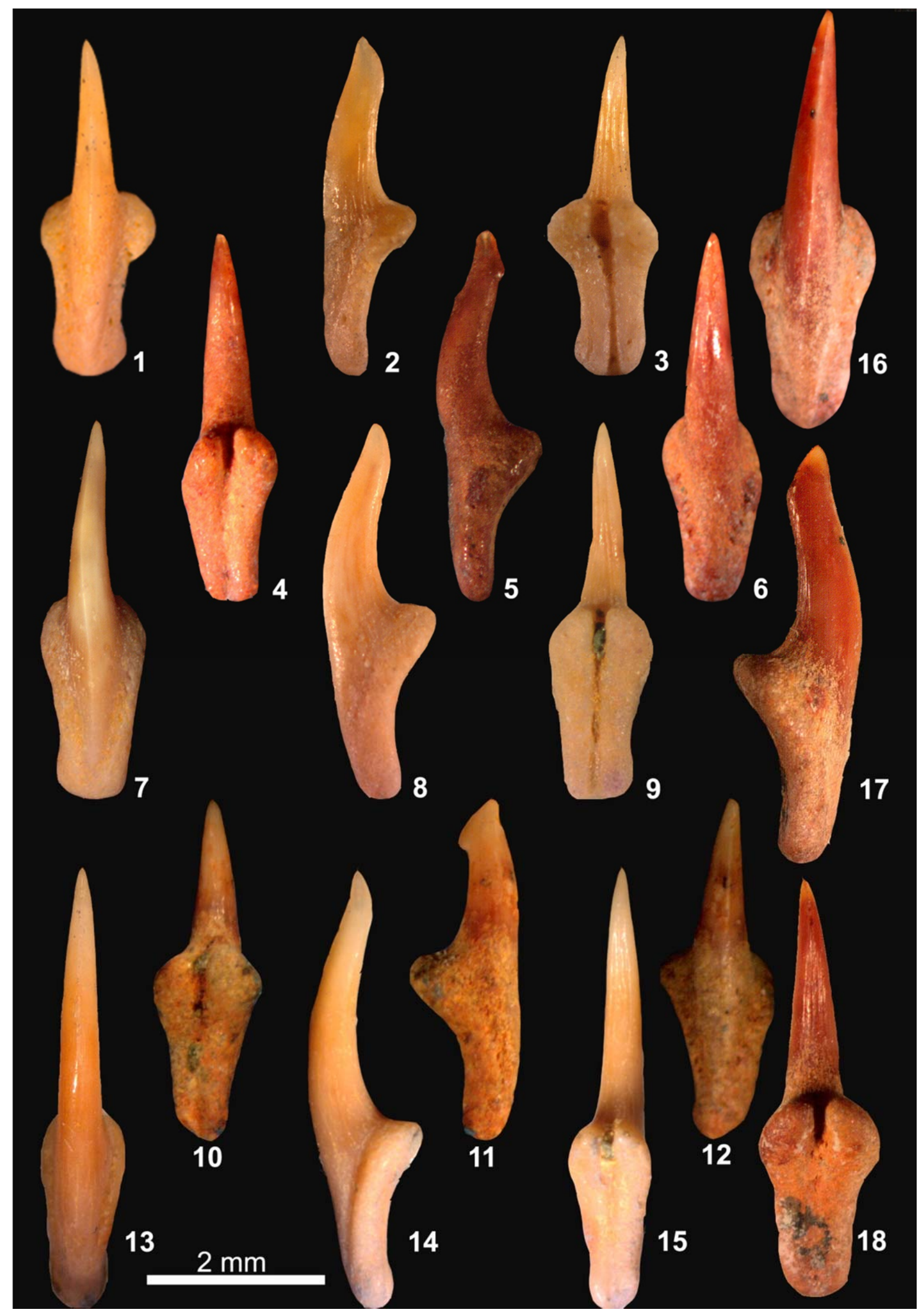




\section{Salame and Asan}

Case, G. R., and Cappetta, H. (1990): The Eocene selachian fauna from the Fayum Depression in Egypt. Palaeontographica Abteilung A, 212: 1-30.

Case, G. R. and West, R. M. (1991): Geology and paleontology of the Eocene Drazinda Shale Member of the Khirthar Formation, central western Pakistan. Part II Late Eocene fishes. Tertiary Res., 12: 105120.

El Aref, M. M. and Lotfy, Z. H. (1989): Genetic karst significance of the iron ore deposits of El Bahariya Oasis, Western Desert, Egypt. Annals of the Geological Survey of Egypt, 15 (1985): 1-30.

El-Sharkawi, M. A., Higazy, M. and Khalil, M. A. (1989): Three probable genetic types of iron ore at El Gedida Mine, Western Desert, Egypt. Egypt. J. Geol., 31/1-2 (1987): 59-71.

Helba, A. A., El Aref, M. M. and Saad, F. (2001): Lutetian oncoidal and ooidal ironstone sequences; depositional setting and origin; northeast El Bahariya depression, Western Desert, Egypt. Egypt. J. Geol., 45/1A: 325-351.

Murray, A. M., Cook, T. D., Attia, Y. S., Chatrath, P., and Simons, E. L. (2010): A freshwater ichthyofauna from the late Eocene Birket Qarun Formation, Fayum, Egypt. Journal of Vertebrate Paleontology, 30/3: 665-680.

Priem, F. (1905): Sur les poissons fossils de l'éocène moyen d'Égypte. Bulletin de la Societé Géologique de France (new series) 5: 633-641.

Said, R. (1990): Cenozoic. In Said, R. (ed.), The geology of Egypt; Balkema, Rotterdam, 451-486.

Said, R. and Issawi, B. (1965): Geology of northern plateau, Bahariya Oasis, Egypt. Geological Survey of Egypt, Paper 29 (1964), 41 p.

Strougo, A., Cappetta, H., and Elnahas, S. (2007): A remarkable Eocene ichthyofauna from the ElGedida glauconitic sandstone, Bahariya oasis, Egypt, and its stratigraphic implications. Publications of the Middle Eocene Research Center, Ain Shams University, Earth Science Series, 21, 81-98.

Tabuce, R., Adnet, S., Cappetta, H., Noubhani, A. and Quillevere, F. (2005): Aznag (bassin d'Ouarzazate, Maroc), nouvelle localité à sélaciens et mammifères de l'Eocène moyen (Lutétien) d'Afrique. Bull. de la Société Géologique de France, 176/4: 381-400.

Underwood, C. J., Ward, D. J., King, C., Antar, S. M., Zalmout, I. S., and Gingerich, P. D. (2011): Shark and ray faunas in the Middle and Late Eocene of the Fayum area, Egypt. Proceedings of the Geologists' Association, 122/1: 47-66. 
New Odontorhytis species from the Eocene of Egypt

نوع Odontorhytis (الأسماك الغضروفية) جليٍ من الإيوسين الأوسط بمنجم الجديدة، الواحات البحرية، مصر

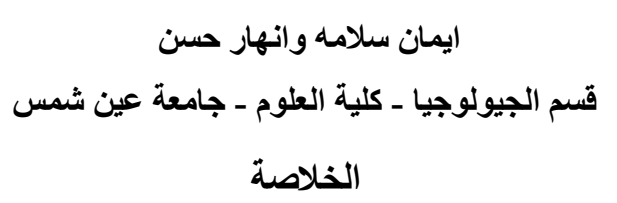

أثثاء دراسة تصنيفية لبعض البقايا المتحفرة للأسماك الغضروفية من الإيوسين الأوسط (علي الأرجح Lutetian) لطبقة

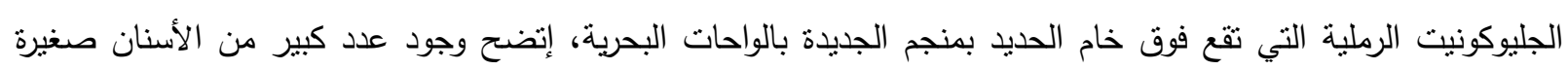

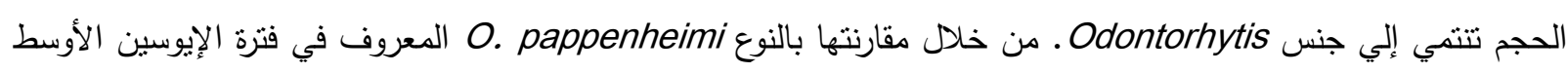
والمتأخر بمصر، إتضح إنها تختلف عن النوع الأخير بمجموعة من الصفات المحددة و الميزة لذللك وجب تعين نوع جدايد

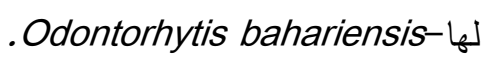

